\title{
ANALISIS PEMASARAN JAGUNG DI DESA DIMEMBE KECAMATAN DIMEMBE KABUPATEN MINAHASA UTARA
}

\author{
Cendy Claudia Wowiling \\ Lyndon R. J. Pangemanan \\ Joachim N. K. Dumais
}

\begin{abstract}
The purpose of this research is to analyze the marketing of corn in each marketing channel in the village of Dimembe, Dimembe Subdistrict, North Minahasa Regency. The data used in this study are primary and secondary data. Primary data was obtained from interviews with 15 farmers while secondary data from the Village Office, North Minahasa Statistics Agency and the North Sulawesi Provincial Statistics Agency. The sampling method used the snowball sampling method. Data analysis methods are analysis of Marketing Channel, Marketing Agency, Marketing Margin and Marketing Costs. The results showed that there were three types of marketing channels, namely the first marketing channel: Farmers to Consumers; second marketing channel 2 from Farmers to Retailers then to Consumers; and the third marketing channel from Farmers to Collector Traders then arrived at the Consumer. Marketing margin on marketing channel I is Rp 213.33 / kg, on marketing channel II is Rp 1,500.00 / kg, and on marketing channel III is Rp 2,500.00/ kg. The highest share received by farmers is in the marketing channel I at 93.90\%. While the lowest share received by farmers is in marketing channel III, which is equal to $58.33 \%$. Thus it can be concluded that the longer the marketing channel, the greater the marketing margin and vice versa. And also the shorter the marketing channel the greater the share received by the farmer and vice versa. "Irr emm".
\end{abstract}

Keywords : Marketing analysis, Corn, Dimembe Village

\begin{abstract}
ABSTRAK
Penelitian ini bertujuan untuk menganalisis pemasaran jagung pada masing-masing saluran pemasaran di Desa Dimembe Kecamatan Dimembe Kabupaten Minahasa Utara. Data yang digunakan dalam penelitian ini adalah data primer dan sekunder. Data primer diperoleh dari wawancara pada 15 petani sedangkan data sekunder dari Kantor Desa, Badan Pusat Statistik Minahasa Utara dan Badan Pusat Statistik Provinsi Sulawesi Utara. Metode pengambilan sampel menggunakan metode snowball sampling. Metode analisis data yaitu Analisis Saluran Pemasaran, Lembaga Pemasaran, Margin Pemasaran dan Biaya Pemasaran. Hasil penelitian menunjukkan terdapat tiga tipe saluran pemasaran yaitu saluran pemasaran pertama: Petani ke Konsumen; saluran pemasaran kedua 2 dari Petani ke Pedagang Pengecer kemudian ke Konsumen; dan saluran pemasaran ke tiga dari Petani ke Pedagang Pengumpul kemudian sampai kepada Konsumen. Margin pemasaran pada saluran pemasaran I sebesar Rp 213,33/kg, pada saluran pemasaran II sebesar Rp $1.500,00 / \mathrm{kg}$, dan pada saluran pemasaran III sebesar Rp $2.500,00 / \mathrm{kg}$. Share paling tinggi yang diterima petani terdapat pada saluran pemasaran I sebesar 93,90\%. Sedangkan share paling rendah yang diterima petani terdapat pada saluran pemasaran III, yakni sebesar 58,33\%. Dengan demikian dapat disimpulkan bahwa semakin panjang saluran pemasaran maka margin pemasaran semakin besar demikian pula sebaliknya. Dan juga semakin pendek saluran pemasaran semakin besar share yang diterima petani demikian pula sebaliknya. "Irtrepm".
\end{abstract}

Kata kunci : Analisis pemasaran, Jagung, Desa Dimembe

Agrisosioekonomi:

Jurnal Transdisiplin Pertanian (Budidaya Tanaman, Perkebunan, Kehutanan, Peternakan, Perikanan), Sosial dan Ekonomi 305 


\section{PENDAHULUAN}

\section{Latar Belakang}

Keberhasilan pada usahatani jagung disinyalir telah menjadi pendorong berkembangnya usahatani pada berbagai komoditas lainnya yaitu perkebunan karet rakyat, sayuran, usaha ternak sapi, dll. Namun demikian, keberhasilan pada usahatani jagung ini dengan sistem kelembagaan pemasaran yang ada masih perlu dibuktikan apakah saluran pemasaran yang tercipta telah benar-benar berjalan secara efisien. Sebab besarnya jumlah produksi dan meluasnya aktivitas usahatani jagung belum menjadi jaminan mencerminkan sistem pemasaran yang efisien, terutama dilihat dari keuntungan yang diterima petani.

Pemasaran merupakan hal yang paling penting dalam menjalankan sebuah usaha pertanian karena pemasaran merupakan tindakan ekonomi yang berpengaruh harga pasar yang rendah, sehingga tingginya produksi tidak mutlak memberikan keuntungan yang tinggi tanpa pemasaran yang baik dan efisien. Secara umum, pemasaran dapat diartikan sebagai segala kegiatan yang dilakukan oleh berbagai perantara dengan berbagai macam cara untuk menyampaikan hasil produksi.

\begin{tabular}{clrrr} 
Tabel & 1. Luas Panen, Produksi & \multicolumn{1}{c}{$\begin{array}{c}\text { dan Produktivitas } \\
\text { Kecamatan di Kabupaten Minahasa Utara, 2016 }\end{array}$} & Menurut \\
\hline NO & Kecamatan & Luas Panen & Produksi & Produktivitas \\
\hline 1 & Kema & 2340 & 10530 & 4.50 \\
2 & Kauditan & 3856 & 17352 & 4.50 \\
3 & Airmadidi & 1805 & 8123 & 4.50 \\
4 & Kalawat & 2302 & 10359 & 4.50 \\
5 & Dimembe & 2521 & 11345 & 4.50 \\
6 & Talawaan & 1944 & 8748 & 4.50 \\
7 & Wori & 1198 & 5305 & 4.43 \\
8 & Likupang Barat & 1414 & 6311 & 4.46 \\
9 & LikupangTimur & 1832 & 8214 & 4.48 \\
10 & Likupang Selatan & 2191 & 9860 & 4.50 \\
\hline & Jumlah & 21.403 & 96.146 & 4.49 \\
\hline
\end{tabular}

Sumber : BPS (BadanPusatStatistik 2017)

Komoditas Pertanian Tanaman Pangan yang paling banyak di Kabupaten Minahasa Utara adalah Padi Sawah dan Jagung, kedua komoditas ini pada tahun 2016 memiliki nilai produksi 43.205 ton untuk padi sawah dan 96.146 ton untuk jagung seperti yang tercantum di table jumlah produksi jagung, dimana kecamatan Dimembe adalah salah satu sentra produksi jagung yang memiliki produktivitas sebanyak 4.50 Ton. Desa dimembe sebagai sentra produk jagung di Kecamatan Dimembe mempunyai 9 kelompok tani dan kelompok-kelompok petani tersebut memasarkan produk jagung kekonsumen yang ada di sekitar Desa Dimembe dan di luar Desa Dimembe.

\section{Pemasaran}

Kegiatan pemasaran sering diartikan sebagai kegiatan dalam memasarakan suatu produk yang diperjual belikan oleh perusahaan dan ditunjukan kepada konsumen, namun jika dilihat makna sebenarnya pemasaran bukan hanya sekedar menjual produk saja, akan tetapi pemasaran juga memiliki aktivitas penting dalam menganalisis dan mengevaluasi segala kebutuhan dan keinginan para konsumen.

Menurut (Wiliam J. Stanto dalam Seftyandi, 2017) marketing is a total system business designed to plan, price, promotion and distribute want satis-flying products to target market to achieve organizational objective "Pemasaran adalah suatu sistem total dari kegiatan bisnis yang dirancang untuk merencanakan, menentukan harga, promosi dan mendistribusikan barang-barang yang dapat memuaskan keinginan dan mencapai pasar sasaran serta tujuan perusahaan. Pemasaran adalah suatu proses kemasyarakatan yang melibatkan individu-individu dan kelompok untuk mendapatkan apa yang mereka butuhkan dan inginkan melalui penciptaan, penawaran, dan pertukaran secara bebas produk dan jasa nilai dengan pihak lain, (Kotler dan Keller dalam buku Dharmmesta, B. S. 2014).

\section{Saluran Pemasaran}

Saluran pemasaran merupakan organisasiorganisasi yang saling tergantung yang tercakup dalam proses membuat produk atau jasa menjadi tersedia untuk digunakan atau dikomsumsi (Abednego, dalam Sambuaga M 2016) menyatakan bahwa, saluran pemasaran adalah himpunan organisasi yang saling bergantung yang terlibat dalam proses untuk membuat produk atau jasa yang siap untuk dikomsumsi atau digunakan oleh konsumen atau penguna industri. Saluran pemasaran terdapat empat desain saluran yang di gunakan dalam mendistribusikan produk, yaitu:

1. Saluran nol-tingkat atau saluran pemasaran langsung (Zero levels channel or direct marketing channel), bentuk saluran ini adalah bentuk saluran yang paling pendek dan sederhana sebab tanpa mengunakan perantara. Produsen dapat menjual barang yang dihasilkan melalui pos atau langsung mendatangi rumah konsumen. 
2. Saluran satu-tingkat (one level), penjulan melalui satu perantara. Didalam saluran pemasaran barang komsumsi, perantara ini merupakan pedagang besar atau grosir, di sini pedagang besar langsung melakukan

3. pembelian pada produsen. Adapula beberapa produsen yang mendirikan toko pengecer sehingga dapat secara langsung melayani konsumen.

4. Saluran dua-tingkat (two level), penjualan yang mempunyai dua perentara yaitu pedangan besar atau grosir dan pengecer, disini produsen hanya melayani pembelian dalam jumlah besar saja tidak menjual kepada pengecer. Pembelian oleh pengecer dilayani pedagang besar dan pembelian oleh konsumen dilayani oleh pengecer saja.

5. Saluran tiga-tingkat (tree level),penjualan yang mempunyai tiga perantara, yaitu pedagang besar (grosir) sebagai pemborong dan pengecer, disini produsen memilih pedagang besar sebagai penyalurnya, dia menjalankan kegiatan perdagangan besar dalam saluran distribusi yang ada. Sasaran penjualannya di tunjukan kepada pengecer besar. panjang pendeknya saluran pemasaran yang dilalui suatu produk pertanian tergantung dari beberapa faktor, antara lain:

a. Jarak antara produsen dan konsumen, semakin jauh jarak makin panjang saluran pemasaran yang di tempuh oleh produk,

b. Cepat tidaknya produk rusak, semakin produk cepat rusak harus cepat sampai ke konsumen, sehingga menghendaki saluran yang pendek dan cepat,

c. Skala produksi, jika produksinya skala kecil maka tidak menguntungkan bila produsen menjualnya langsung ke pasar, sehingga saluran pemasaran yang di lalui cendrung panjang,

d. Posisi keuangan pengusaha, produsen yang posisi keuangannya kuat, cenderung untuk memperpendek saluran pemasaran.

\section{Farmer Share}

Farmer share dapat dihitung berdasarkan persentase jumlah harga yang di terima oleh petani/produsen dibagi dengan harga yang terbentuk pada konsumen akhir. Dimana makin besar marjin pemasaran maka bagian yang diterima petani makin kecil bagian yang diterima oleh petani dan sebaliknya (Tomek dan Robinson dalam Sambuaga M 2016).

\section{Rumusan Masalah}

Masalah yang ada dalam usulan penelitian ini adalah, menganalisis bagaimana pemasaran jagung di Kecamatan Dimembe melalui saluran-saluran pemasaran yang ada di Desa Dimembe.

\section{Tujuan Penelitian}

Tujuan dari penelitian ini adalah untuk menganalisis pemasaran jagung pada masingmasing saluran pemasaran di Desa Dimembe, Kecamatan Dimembe, Kabupaten Minahasa Utara.

\section{Manfaat Penelitian}

Manfaat dari penelitian ini adalah sebagai masukan bagi petani jagung di daerah penelitian untuk memperbaiki kinerja dari masing-masing saluran agar lebih efisien dan memperbaiki fungsi-fungsi pemasaran.

\section{METODE PENELITIAN}

\section{Lokasi dan Waktu Penelitian}

Lokasi yang menjadi sampel penelitian yaitu Desa Dimembe, Kecamatan Dimembe, Kabupaten Minahasa Utara. Dengan pertimbangan bahwa Kecamatan Dimembe adalah salah satu sentra produksi jagung yang memiliki produktivitas 4.50 ton. Waktu penelitian yaitu 2 bulan di mulai pada bulan Maret sampai bulan Mei 2018 mulai dari persiapan sampai pengumpulan data.

\section{Metode Pengumpulan Data}

Metode yang digunakan dalam penelitian ini adalah metode deskriptif yaitu mengunakan data primer dan sekunder, untuk mendapatkan data primer digunakan dengan cara wawancara langsung. Sedangkan data sekunder di peroleh dari sumber-sumber yang berhubungan dengan objek penelitian, yaitu Kantor Desa, Badan Pusat Statistik Minahasa Utara dan Badan Pusat Statistik di Sulawesi Utara.

\section{Metode Pengambilan Sampel}

Metode pengambilan sampel di Desa Dimembe terdapat 9 kelompok tani. Dari kelompok tersebut diambil 3 kelompok tani yang paling aktif, dari masing-masing kelompok 
tersebut di ambil 5 petani produsen jagung. Dari 15 petani tersebut di telusuri dengan menggunakan snowball sampling, pedagangpedagang hingga ketingkat konsumen akhir jagung.

\section{Konsep Pengukuran Variabel}

Variabel dan satuan ukuran dalam penelitian yaitu:

1. Saluran pemasaran jagung adalah rantai pemasaran jagung dari produsen sampai ke konsumen akhir.

2. Harga ditingkat petani adalah penerimaan harga petani jagung dari lembaga pemasaran, dinyatakan dalam satuan $\mathrm{Rp} / \mathrm{kg}$.

3. Harga ditingkat pedagang pengumpul adalah harga yang diterima dari pedagang pengumupul dari hasil penjualan kepada pedagang pengecer, dinyatakan dalam satuan $\mathrm{Rp} / \mathrm{kg}$.

4. Harga ditingkat pedagang pengecer adalah harga yang diterima dari pedagang pengecer dari hasil penjualan kepada konsumen, dinyatakan dalam satuan $\mathrm{Rp} / \mathrm{kg}$.

5. Biaya pemasaran adalah semua biaya yang di keluarkan oleh lembaga pemasaran dalam memasarkan jagung, dinyatakan dalam satuan $\mathrm{Rp} / \mathrm{kg}$.

\section{Metode Analisis Data}

Metode analisis data yang akan digunakan dalam penelitian di Desa Dimembe, Kecamatan Dimembe adalah:

1. Untuk menganalisis saluran pemasaran dan lembaga pemasaran jagung yang ada di Desa Dimembe, Kecamatan Dimembe, menggunakan metode analisis deskriptif.

2. Untuk mengetahui marjin pemasaran dan biaya pemasaran di tingkat lembaga dalam saluran pemasaran digunakan analisis marjin pemasaran yaitu dengan menghitung besarnya biaya, keuntungan, dan marjin pemasaran pada tiap lembaga perantara pada berbagai saluran pemasaran.

a. Marjin Pemasaran adalah selisih harga tingkat konsumen akhir dengan harga produsen. Menurut (Tomek dan Robinson dalam Simon 2001) marjin pemasaran dihitung dengan mengunakan rumus sebagai berikut:

$$
\mathbf{M}=\mathbf{P r}-\mathbf{P f}
$$

dimana:

$\mathrm{M}$ : Marjin pemasaran $\mathrm{Rp} / \mathrm{kg}$ )
$\operatorname{Pr}$ : Harga ditingkat konsumen $(\mathrm{Rp} / \mathrm{kg})$

Pf : Harga ditingkat produsen $(\mathrm{Rp} / \mathrm{kg})$

b. Biaya Pemasaran adalah biaya yang di keluarkan untuk memasarkan suatu komoditi dari produsen ke konsumen. (Tomek dan Robinson 2011), Biaya pemasaran dapat di rumuskan sebagai berikut:

dimana:

$$
B p=B p 1+B p 2+B p 3 \ldots+B p n
$$

Bp : Biaya pemasaran jagung $(\mathrm{Rp} / \mathrm{kg})$

Bp1,2,3..n : Biaya pemasaran tiap lembaga pemasaran $(\mathrm{Rp} / \mathrm{kg})$

c. Keuntungan Pemasaran Menurut (Tomek dan Robinson dalam Simon 2001), Untuk mengetehaui besarnya profit marjin setiap lembaga pemasaran digunakan perhitungan sebagai berikut:

dimana:

$$
\mathbf{P}=\mathbf{M}-\mathbf{C}
$$

$\mathrm{P}=$ Keuntungan Marjin $(\mathrm{Rp} / \mathrm{kg})$

$\mathrm{M}=$ Harga di tingkat pedagang $(\mathrm{Rp} / \mathrm{kg})$

$\mathrm{C}=$ Biaya Pemasaran $(\mathrm{Rp} / \mathrm{kg})$

3. Farmer share, dapat dihitung berdasarkan persentase jumlah harga yang di terima oleh petani/produsen dibagi dengan harga yang terbentuk pada konsumen akhir. Secara sisitematis dapat di rumuskan sebagai berikut:

\section{Fs $=$ pf $/$ ps $\times 100$}

dimana :

Fs : Farmer Share

Pf : Harga di tingkat petani

Pr : Harga di tingkat konsumen

\section{HASIL DAN PEMBAHASAN}

\section{Deskripsi Wilayah Pertanian}

\section{Letak dan Luas Wilayah}

Desa Dimembe berada pada ketinggian 200 mdpl (meter diatas permukaan laut), memiliki luas 2.190 ha. Batas wilayah administratif Desa Matungkas sebagai berikut:

1. Sebelah Utara : Desa Warukapas, Kecamatan Dimembe

2. Sebelah Timur: Desa Klabat, Kecamatan Dimembe

3. Sebelah Selatan : Desa Laikit, Kecamatan Dimembe

4. Sebelah Barat : Desa Tetey, Kecamatan Dimembe 
Jarak kantor desa dengan ibukota kecamatan $3 \mathrm{~km}$, dan jarak kantor desa dengan ibukota kabupaten $4 \mathrm{~km}$.

\section{Penduduk di Desa Dimembe}

Jumlah penduduk Desa Dimembe adalah 2.475 jiwa. Jumlah laki-laki 1.240 jiwa dan jumlah perempuan 1.235 jiwa.

\section{Mata pencaharian}

Mata pencaharian penduduk Desa Dimembe umumnya bersumber dari hasil-hasil pertanian salah satunya budidaya Jagung. Selain berprofesi sebagai petani, penduduk yang ada di Desa Dimembe juga ada yang bermata pencarian sebagai tukang ojek, pegawai sipil, dan wiraswasta.

\section{Karakteristik Responden}

Gambaran secara umum dalam menjalankan suatu kegiatan usahatani baik yang bersifat subsistem maupun usahatani yang sudah komersil, dalam menjalankan usahatani dipengaruhi oleh beberapa faktor, yaitu: umur dari petani itu sendiri, tingkat pendidikan dan luas lahan yang diusahakan.

\section{Umur Petani Responden}

Umur Petani Responden Keadaan penduduk berdasarkan kelompok umur dapat di bedakan menjadi dua kelompok yaitu penduduk usia produktif dan penduduk usia non produktif. Tabel 2 menjelaskan tentang umur dan jumlah petani yang menjadi sampel di Desa Dimembe.

Tabel 2 menunjukkan bahwa jumlah petani responden yaitu 15 orang yang semuanya masih berusia produktif. 7 orang atau 46,67 persen berada pada kisaran berumur 25-40 tahun, kemudian diikuti 5 orang atau 33,33 persen dengan kisaran umur 41-60. Sedangkan kisaran umur $61-75$ tahun berjumlah 3 orang atau 20.00 persen.

Tabel 2. Umur Petani yang menjadi Sampel di Desa Dimembe

\begin{tabular}{clcr}
\hline No & $\begin{array}{l}\text { Kelompok } \\
\text { Umur (Tahun) }\end{array}$ & Jumlah (Orang) & Persentase (\%) \\
\hline 1 & $30-60$ & 7 & \\
2 & $61-70$ & 5 & 46.67 \\
3 & $\geq 80$ & 3 & 33.33 \\
\hline & Jumlah & 15 & 20.00 \\
\hline
\end{tabular}

Sumber : Diolah dari data primer, 2018

\section{Tingkat Pendidikan Petani}

Pendidikan petani responden merupakan salah satu faktor penting menerima dan menerapkan teknologi baru disamping kemampuan dan keterampilan petani itu sendiri. Disamping itu sangat mempengaruhi pola pikir dan pengambilan keputusan dalam usahatani jagung dan pemasaran yang dihasilkan. Tabel 3 menjelaskan tentang tingkat pendidikan petani yang membudidayakan jagung yang menjadi sampel di Desa Dimembe.

Tabel 3. Tingkat Pendidikan Petani di Desa Dimembe

\begin{tabular}{|c|c|c|c|}
\hline No & Tingkat Pendidikan & Jumlah Petani (Orang) & Persentase $(\%)$ \\
\hline 1 & SD & 8 & 53,33 \\
\hline 2 & SLTP & 3 & 20.00 \\
\hline 3 & SLTA & 4 & 26,67 \\
\hline 4 & Perguruan Tinggi & - & - \\
\hline & Jumlah & 15 & 100.00 \\
\hline
\end{tabular}

Tabel 3 menunjukkan bahwa persentase petani yang tamat SD sebesar 8 atau 53,33 persen dari total jumlah petani responden, kemudian diikuti dengan tingkat pendidikan SLTP sebanyak 3 orang atau 20,00 persen. Sedangkan pada tingkat SLTA sebanyak 4 orang atau 26,67 persen. Persentase pendidikan petani di Desa Dimembe yang hanya tamatan SD yang lebih dominan ini disebabkan karena masyarakat yang usia lanjut pada masa itu belum terfasilitasi untuk menempuh pendidikan yang lebih tinggi serta kurangnya kesadaran akan pentingnya pendidikan bagi sebagian penduduk, hal ini disebakan karena alasan ekonomi yang rendah, sehingga tidak mampu mengenyam pendidikan yang lebih tinggi. Walaupun hanya tamatan sekolah dasar. Para petani mampu bertani jagung dengan produksi yang cukup banyak. Ini dikarenakan para petani jagung sudah lama mendapatkan keterampilan tersebut dengan mengikuti pelatihan dan saling berbagi pendapat pada para petani jagung lain ataupun para orang tua yang sudah sejak lama mengetahui tentang cara bertani jagung.

\section{Luas Penggunaan Lahan Usahatani Jagung}

Luas lahan usaha tani merupakan keseluruhan luas lahan yang di usahakan petani responden baik milik sendiri, menyewa, maupun meyakap. Luas lahan hasil penelitian berada pada kisaran luas lahan 0,5-2 ha. Luas lahan usahatani menentukan pendapatan, taraf hidup dan derajat kesejahtraan rumah tangga petani, karena semakin luas lahan usahatani 
maka akan semakin tinggi hasil produksi sehingga turut meningkatkan pendapatan petani. Tabel 4 menjelaskan tentang luas lahan garapan petani yang menajadi sampel di Desa Dimembe.

Tabel 4. Luas Pemilikan Lahan Petani Jagung

\begin{tabular}{|c|c|c|c|c|}
\hline No & Luas Tanam (Ha) & $\begin{array}{c}\text { Jumlah } \\
\text { Produksi (Kg) }\end{array}$ & $\begin{array}{l}\text { Jumlah } \\
\text { Petani }\end{array}$ & Persentase (\%) \\
\hline 1 & 0,5 & 500 & 5 & 33,33 \\
\hline 2 & 1 & 1000 & 6 & 40,00 \\
\hline 3 & 2 & 2000 & 4 & 26,67 \\
\hline & Jumlah & 3500 & 15 & 100.00 \\
\hline
\end{tabular}

Tabel 4 menunjukkan bahwa Luas lahan yang dimiliki petani yaitu 0,5 ha sebanyak 6 orang atau 40,00 dengan jumlah produksi $500 \mathrm{~kg}$, Kemudian diikuti dengan luas lahan satu ha sebanyak 5 orang atau 33,33 persen jumlah produksi $1000 \mathrm{~kg}$. Sedangkan luas lahan 2 ha yang petani sebanyak 3 orang atau 26,67 persen dengan jumlah produksi $2000 \mathrm{~kg}$. Produksi yang di hasilkan pada tiap lahan berbeda-beda karena disebabkan oleh keadaan tanaman dan jumlah yang di hasilkan. Dalam 1 Ha dapat menghasilkan 100kg jagung.

\section{Identitas Responden Lembaga Pemasaran}

Pedagang atau lembaga pemasaran yang terlibat dalam pemasaran jagung di Desa Dimembe adalah pedagang pengumpul dan pedagang pengecer. Dari petani menjual jagung ke pedagang pengumpul dan pedagang pengecer. Layaknya suatu pengalaman dan pola pikir yang cermat yang dalam hal ini umur dan pendidikan sangat mempengaruhi keberhasilan dalam berdagang.

\section{Pedagang Pengumpul}

Pedagang pengumpul pada umumnya mendapatkan jagung langsung dari petani. Tabel 5 menjelaskan tentang umur dan tingkat pendidikan pedagang pengumpul yang menjadi sampel di Desa Dimembe.

Tabel 5. Umur dan Tingkat Pedidikan Pedagang Pengumpul Yang Menjadi Sampel

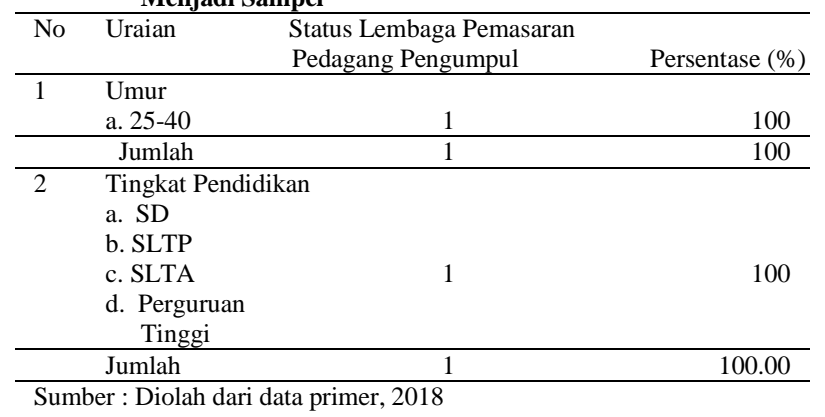

Hasil penelitian diketahui bahwa jumlah responden pedagang pengumpul jagung hanya 1 orang. Tingkat pendidikan responden pedagang pengumpul dalam pemasaran jagung adalah tamatan SLTA. Sesuai hasil penelitian pedagang pengumpul hanya 1 orang karena dari 15 petani tersebut sebagian hasil produksi jagung hanya dijual kepada 1 orang pedagang pngumpul.

\section{Pedagang Pengecer}

Tingkat umur seseorang sangat mempengaruhi kemampuanya untuk bekerja secara efektif. Tabel 6 ini menjelaskan tentang identitas dan tingkat pendidikan pedagang pengumpul yang menjadi sampel dalam penelitian di Desa Dimembe.

\begin{tabular}{|c|c|c|c|}
\hline No & Uraian & $\begin{array}{l}\text { Status Lembaga Pemasaran } \\
\text { Pedagang Pengumpul }\end{array}$ & Persentase (\%) \\
\hline \multirow[t]{5}{*}{1} & Umur & & \\
\hline & a. $25-40$ & 3 & 60 \\
\hline & b. $41-50$ & 1 & 20 \\
\hline & c. $\geq 60$ & 1 & 20 \\
\hline & Jumlah & 5 & 100 \\
\hline \multirow[t]{7}{*}{2} & Tingkat Pendidikan & & \\
\hline & b. SD & - & - \\
\hline & b. SLTP & 1 & 20,00 \\
\hline & c. SLTA & 4 & 80,00 \\
\hline & d. Perguruan & & \\
\hline & Tinggi & - & - \\
\hline & Jumlah & 5 & 100.00 \\
\hline
\end{tabular}

Sumber : Diolah dari data primer, 2018

Hasil penelitian menunjukan variasi umur pedagang pengumul responden, dimana hasil penelitian di dapat umur relative yang bekerja adalah berumur 25-40 tahun yaitu sebanyak 3 orang atau 60,00 persen, kemudian diikuti dengan kelompok umur 41-50 sebanyak 1 orang atau 20,00 persen. Selanjutnya kelompok umur diatas 60 tahun berjumlah 1 orang atau 20,00 persen. Tingkat pendidikan SD sesuai penelitian yaitu tidak ada, diikuti dengan tingkat pendidikan SLTP sebanyak 1 orang atau 00,00 persen. Sedangkan pada tingkat SLTA sebanyak 4 orang atau 80,00 persen.

\section{Fungsi Lembaga Pemasaran}

Fungsi-fungsi pemasaran adalah mengusahakan agar pembeli atau konsumen memperoleh barang yang diinginkan pada tempat, waktu, dan harga yang tepat. Fungsi-fungsi pemasaran dalam pelaksanaan aktifitasnya dilakukan oleh lembaga-lembaga pemasaran. Lembaga pemasaran ini yang akan terlibat dalam 
proses penyampaian barang dan jasa dari produsen sampai ke tangan konsumen. Fungsi fungsi pemasaran meliputi fungsi pertukaran, fungsi fisik dan fungsi fasilitas (lihat Tabel 7).

\begin{tabular}{|c|c|c|}
\hline No & Lembaga Pemasaran & Fungsi Lembaga Pemasaran \\
\hline 1 & Petani & $\begin{array}{l}\text { 1. Fungsi Pertukaran terdiri dari : } \\
\text { a. Fungsi Pengumpul, Penyimpanan, } \\
\text { dan Penjualan }\end{array}$ \\
\hline 2 & Pedagang Pengumpul & $\begin{array}{l}\text { 1. Melakukan fungsi pertukaran terdiri dari: } \\
\text { a. Fungsi Pembelian } \\
\text { b. Fungsi Penjualan } \\
\text { 2. Melakukan fungsi Fisik terdiri dari: } \\
\text { a. Fungsi penanggungan resiko }\end{array}$ \\
\hline 3 & Pedagang Pengecer & $\begin{array}{l}\text { 1. Melakukan fungsi pertukaran terdiri dari: } \\
\text { a. Fungsi Pembelian } \\
\text { b.Fungsi Penjualan } \\
\text { 2. Melakukan fungsi Fisik terdiri dari: } \\
\text { a.. Fungsi Penyimpanan } \\
\text { b. Melakukan fungsi pengangkutan } \\
\text { 3. Melakukan Fungsi Fasilitas terdiri dari: } \\
\text { a. Fungsi penganggungan resiko }\end{array}$ \\
\hline
\end{tabular}

\section{Petani}

Produsen jagung umumnya melakukan fungsi pertukaran yaitu kegiatan mengumpul, menyimpan dan juga menjual produksi jagung ke pasar-pasar tradisional. Produsen menjual jagung produksinya kepada pedagang pengumupul, dan kadangkala menjual langsung kepada pedagang pengecer. Tujuannya adalah mendapatkan tingkat harga yang lebih baik dalam melakukan kegiatan pemasaran.

\section{Pedagang Pengumpul}

Pedagang pengumpul melakukan fungsi pertukaran yaitu membeli jagung dari produsen dan menjual kembali kepada pedagang pengecer. Fungsi fisik yaitu:

(1) Fungsi penyimpanan dilakukan apabila sewaktu-waktu jagung yang di jual pedagang pengumpul tidak laku terjual.

(2) Fungsi pengangkutan dilakukan menggunakan pik up). Fungsi fasilitas yaitu fungsi penaggungan resiko adalah pedagang pengumpul menanggung resiko adanya jagung yang rusak, selama proses pengangkutan dan resiko barang yang diangkut tidak habis terjual.

\section{Pedagang Pengecer}

Melakukan fungsi pertukaran yakni kegiatan pembelian dari pihak produsen dan pedagang pengumpul, dan melakukan penjualan langsung kepada konsumen dalam bentuk jagung pipil fungsi fisik yaitu: (1) fungsi penyimpanan dilakukan apabila sewaktu-waktu jagung yang di jual pedagang pengumpul tidak laku terjual. (2) fungsi pengangkutan dilakukan menggunakan motor. Fungsi fasilitas yaitu fungsi penaggungan resiko adalah pedagang pengecer menanggung resiko adanya jagung yang rusak, selama proses pengangkutan dan resiko barang yang diangkut tidak habis terjual.

\section{Pemasaran Jagung}

Jagung merupakan tanaman semusim (annual). Satu siklus hidupnya diselesaikan dalam 80-150 hari. Paruh pertama dari siklus merupakan tahap pertumbuhan vegetatif dan paruh kedua untuk tahap pertumbuhan generatif. Jagung bisa di panen stelah berusia 120-130 hari setelah tanam untuk memastikan benar-benar kering Jagung yang siap panen memiliki ciri-ciri kelobot cokelat rambut jagung hitam kering, biji jagung keras.Petani dapat menjual Jagung kepada pedagang pengumpul yang berada di desa atau di pedagang pengecer kios-kios yang ada di desa Dimembe. Bila di lihat dari transportasi, diatas dikatakan mudah karena pedagang pengumpul dan pedagang pengecer hanya yang berada di desa Dimembe.

Pedagang pengumpul dan pedagang pengecer langsung datang ke petani untuk membeli jagung. Jagung yang dijual petani di hitung perkilogram. Pedagang pengumpul menjual ke pedagang pengecer dan di pasar tradisional. Petani juga menjual kepada pedagang pengecer yang ada di Desa Dimembe.

\section{Saluran Pemasaran}

Kegiatan pendistribusian jagung dari petani ke konsumen memerlukan pedagang perantara atau disebut juga sebagai lembaga pemasaran yang mempunyai peranan penting dalam kegiatan pemasaran. Penyaluran hasil produksi dari produsen ke konsumen melalui lebih dari satu saluran pemasaran dimana masing masing saluran melibatkan lembaga pemasaran yang tidak sama.

Di Desa Dimembe hanya melibatkan sedikit lembaga pemasaran sehingga pemasaran menjadi pendek. Saluran pemasaran jagung di Desa Dimembe melibatkan tiga lembaga pemasaran, yakni produsen, pedagang pengumpul, pedagang pengecer di desa. Lembaga pemasaran yang terlibat dalam saluran 
pemasaran jagung ini harus melakukan fungsifungsi pemasaran, dengan adanya fungsi-fungsi pemasaran dapat mempermudah konsumen untuk mendapatkan apa yang mereka butuhkan. Dalam pemasaran, barang mengalir dari produsen sampai kepada konsumen akhir yang di sertai penambahan guna tempat melalui proses pengangkutan dan guna waktu melalui proses penyimpanan.

Saluran pemasaran jagung berdasarkan penelitian di Desa Dimembe Kecamatan Dimembe adalah sebagai berikut:
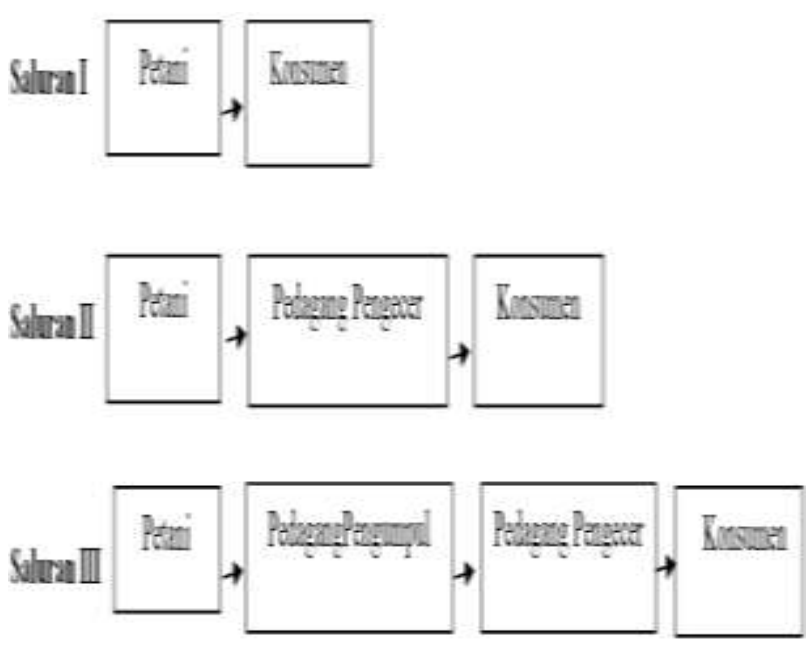

Keterangan:

\section{Saluran Pemasaran I}

Pola pemasaran saluran pertama ini yaitu (petani-konsumen) sebanyak 3 orang $(20,00 \%)$ Saluran Pemasaran ini merupakan saluran pemasaran dengan volume penjualan paling kecil dari produsen. Saluran pemasaran ini tidak menggunakan lembaga pemasaran manapun, dan oleh karena itu merupakan saluran yang memiliki rantai paling pendek. Dimana petani langsung menjual jagung kepada konsumenkonsumen yang ada di wilayah Desa Dimembe. Pada saluran pemasaran ini, harga jual jagung dari produsen ke kensumen seharga Rp $3.286,67 / \mathrm{kg}$.

Saluran pemasaran pertama ini memiliki sasaran konsumen yang berada di sekitar lokasi budidaya produsen, yakni konsumen yang sewaktu-waktu ingin membeli jagung tanpa harus ke pasar dan juga konsumen menghubungi langsung ke pada produsen.

\section{Saluran Pemasaran II}

Pola saluran pemasaran II terdiri dari petani, dan pedagang pengecer ke konsumen, petani yang memilih saluran ini sebanyak 5 orang (33,33 persen) dari 15 petani responden. Petani sebagai penjual tidak mengeluarkan biaya transportasi akan tetapi biaya transportasi di tanggung oleh pedagang pengecer(warung). Pada saluran pemasaran II petani langsung menjual ke pedagang pengecer (warung) yang ada di desa Dimembe. Kegiatan penjualan dengan cara pedagang pengecer mendatangi petani di rumah. Adapun cara pembayaran yang di lakukan dari pedagang pengecer ke petani dengan cara pembayaran tunai setelah menerima jagung. Pengangkutan jagung hanya meakukan kendaraan beroda dua karena jaraknya tidaklah jauh.

Harga jual jagung dari produsen ke pedagang pengecer $\mathrm{Rp} 3.500 / \mathrm{kg}$ kemudian dari pedagang pengecer ke konsumen dengan harga $5.000 / \mathrm{kg}$.

\section{Saluran Pemasaran III}

Pola saluran pemasaran ini terdapat 3 alur yaitu: petani-pedagang pengumpul pedagang pengecer konsumen adalah sebanyak 7 orang atau 46,67 persen dari 15 responden petani. Saluran pemasaran ini menggunakan dua lembaga pemasaran di antara produsen dan konsumen, yakni pedagang pengumpul sebanyak 1 orang dan pedagang pengecer sebanyak 2 orang. Pedagang pengumpul membeli jagung dari petani dalam jumlah yang lebih banyak, yaitu berkisar $11.500 \mathrm{~kg}$. Pedagang pengumpul menjual jagungnya ke pedagang pengecer menjual ke luar daerah di Kab. Sangihe dan ke pasar. Harga jual jagung dari produsen ke pedagang pengumpul berkisar antara $\mathrm{Rp} 3.500 / \mathrm{kg}$ dan harga jual pedagang pengumpul ke pedagang pengecer $\mathrm{Rp}$ $\mathrm{Rp} 4.000 / \mathrm{kg}$ dan harga jual ke konsumen berkisar antara $\mathrm{Rp} 6.000 / \mathrm{kg}$.

\section{Marjin Pemasaran}

Marjin pemasaran meupakan perbedaan harga ditingkat petani atau produsen dan harga ditingkat konsumen. Termasuk dalam marjin pemasaran ini adalah seluruh biaya yang dikeluarkan oleh lembaga pemasaran mulai dari tingkat petani atau prosusen sampai pedagang pengumpul dan pedagang pengecer dalam proses pemasaran. 


\section{Marjin Pemasaran Pada Saluran Pemasaran pertama}

Perbedaan besarnya biaya pemasaran yang harus dikeluarkan oleh lembaga-lembaga pemasaran akan menyebabkan perbedaan harga, karena masing-masing berusaha untuk memperoleh keuntungan dari proses pemasaran tersebut. Harga jual, harga beli dan biaya pemasaran akan menunjukkan besarnya keuntungan yang diperoleh setiap lembaga pemasaran dan akan berpengaruh terhadap marjin pemasaran. Besarnya biaya, keuntungan dan marjin pemasaran pada saluran pemasaran pertama dapat dilihat pada Tabel 8 .

Tabel 10. Komponen Biaya, Keuntungan, Marjin Pemasaran dan Persentase Jagung Pada Saluran Pemasaran III di Desa Dimembe

\begin{tabular}{|c|c|c|c|}
\hline No & Komponen Biaya & Harga $(\mathrm{Rp} / \mathrm{Kg})$ & Persentase (\%) \\
\hline \multirow[t]{2}{*}{1} & Petani & & \\
\hline & Harga Jual & $3.500,00$ & 58,33 \\
\hline \multirow[t]{8}{*}{2} & Pedagang Pengumpul & & \\
\hline & Harga Jual & $4.000,00$ & 66,67 \\
\hline & Biaya Pemasaran : & & \\
\hline & 1. Transportasi & 10,00 & 0,17 \\
\hline & 2. Karung & 80,00 & 1,33 \\
\hline & Total Biaya & 90.00 & 1,50 \\
\hline & Keuntungan & 410.00 & 6,83 \\
\hline & Margin Pemasaran & 500,00 & 8,33 \\
\hline \multirow[t]{11}{*}{3} & Pedagang Pengecer & & \\
\hline & Harga Jual & $6.000,00$ & 100,00 \\
\hline & Biaya Pemasaran : & & \\
\hline & 1. Pengangkutan & 400.00 & 6,67 \\
\hline & 2. Karung & 80,00 & 1,33 \\
\hline & Total Biaya & 480.00 & 8,00 \\
\hline & Keuntungan & 1.520 .00 & 25,33 \\
\hline & Margin Pemasaran & $2.000,00$ & 33,33 \\
\hline & Total Biaya Pemasaran & 570,00 & 8,17 \\
\hline & Total Keuntungan & $1.930,00$ & 51,83 \\
\hline & Total Margin Pemasaran & $2.500,00$ & 41,67 \\
\hline
\end{tabular}

Tabel 10 menunjukkan bahwa total biaya pemasaran yang dikeluarkan oleh pedagang pengumpul desa yaitu sebesar Rp. 90,00/kg atau 1,50 persen sedangkan total biaya yang dikeluarkan oleh pedagang pengecer yaitu sebesar Rp. $480,00 / \mathrm{kg}$ atau 8,00 persen. Hal ini disebabkan karena pedagang pengecer menanggung

biaya pengangkutan yang ada di atas kapal. Pedagang pengumpul memperoleh keuntungan sebesar Rp. 410,00/kg atau 16,50 persen dan pedagang pengecer mendapatkan keuntungan sebesar Rp. $1.520 .000 / \mathrm{kg}$ atau 25,33 persen. Keuntungan tertinggi diperoleh pedagang pengecer dengan margin pemasaran sebesar Rp. $2.000 / \mathrm{kg}$ atau 33,33 persen. Hal ini disebabkan karena pedagang pengecer membeli jagung dengan jumlah yang besar.

\section{Farmer Share}

Farmer share merupakan perbandingan antara harga yang diterima oleh petani jagung dengan harga yang dibayarkan oleh konsumen akhir. Besarnya farmer share akan mempengaruhi nilai marjin pemasaran dan semakin banyak lembaga pemasaran yang terlibat dalam saluran pemasaran maka akan mempengaruhi farmer share (Widayanti, 2008). Nilai farmer share pada setiap saluran pemasaran yang terbentuk dari kegiatan pemasaran jagung, dapat dilihat pada Tabel 11 .

Hal ini disebabkan karena harga yang diterima petani rendah akibat keterkaitan modal yang dimilki kepada pedagang sehingga petani siap menerima harga pasar yang ditentukan oleh pedagang.

Tabel 11. Farmer's Share pada Saluran Pemasaran Jagung dari Desa Dimembe Kecamatan Dimembe Kab. Minahasa Utara

\begin{tabular}{llrrr}
\hline No & \multicolumn{4}{c}{ Saluran } \\
Pemasaran & $\begin{array}{r}\text { Harga di } \\
\text { Tingkat } \\
\text { Petani } \\
(\mathrm{Rp} / \mathrm{Kg})\end{array}$ & $\begin{array}{r}\text { Harga di } \\
\text { Tingkat } \\
\text { Konsumen } \\
(\mathrm{Rp} / \mathrm{Kg})\end{array}$ & $\begin{array}{r}\text { Farmer's } \\
\text { Share }(\%)\end{array}$ \\
\hline 1 & Saluran I & $3.286,67$ & $3.500,00$ & 93,90 \\
2 & Saluran II & $3.500,00$ & $5.000,00$ & 70,00 \\
3 & Saluran III & $3.500,00$ & $6.000,00$ & 58,33 \\
\hline
\end{tabular}

Tabel 11 menunjukkan bahwa nilai farmer's share tertinggi berada pada saluran pemasaran pertama yaitu sebesar 93,90 persen karena petani menjual langsung ke konsumen dengan biaya pemasaran yang sedikit, sedangkan farmer's share terendah diperoleh saluran pemasaran ke tiga karena pada saluran ini memiliki rantai pemasaran yang lebih panjang dan biaya-biaya pemasaran yang relative lebih besar dibandingkan dengan ke dua saluran pemasaran yang ada, walaupun farmer share pada saluran pemasaran ketiga ini terendah akan tetapi jumlah penjualanya yang paling besar yaitu berjumlah $11.500 \mathrm{~kg}$.

\section{KESIMPULAN DAN SARAN}

\section{Kesimpulan}

Total margin pemasaran pada saluran pemasaran I sebesar Rp 213,33/kg, pada saluran pemasaran II sebesar Rp 1.500,00/kg, dan pada saluran pemasaran III sebesar Rp 2.500,00/kg. 
Dengan demikian dapat dibuktikan bahwa semakin panjang saluran pemasaran maka margin pemasaran semakin besar.

Share paling tinggi yang diterima petani ada pada saluran pemasaran I sebesar 93,90\%. Sedangkan share paling rendah yang diterima petani terdapat pada saluran pemasaran III, yakni sebesar 58,33\%. Makin tinggi perbedaan harga petani dan konsumen menyebabkan share yang diterima petani semakin kecil. Rendahnya share yang diterima petani menunjukkan bahwa petani tidak cukup terlibat dalam proses pembentukan harga.

Dapat dilihat dari share dengan menggunakan rumus dimana share yg tertinggi, terdapat pada saluran pertama, yaitu merupakan saluran yang baik untuk digunakan akan tetapi, pada pemasaran jagung di Desa Dimembe ini, Jumlah keuntungan yang ada pada saluran pemasaran I yaitu yang terkecil karena petani yang menanggung biaya pemasaran, dan jumlah jagung yang dijual adalah yang paling sedikit.

Sesuai dengan hasil pemasaran ini, Jumlah yang banyak dipasarkan terdapat pada saluran pemasaran III, walaupun share pada saluran ini yang terendah akan tetapi jumlah penjualanya yang paling besar yaitu berjumlah $11.500 / \mathrm{kg}$.

\section{Saran}

Petani hendaknya mempertimbangkan terlebih dahulu saluran pemasaran mana yang tepat untuk memasarkan hasil produksinya sehingga bisa memperoleh keuntungan yang lebih tinggi.

\section{DAFTAR PUSTAKA}

Sambuaga, J. M., \& Rumagit, G. A. R. A. 2016. Analisis Pemasaran Buah Pepaya di Desa Matungkas Kecamatan Dimembe Kabupaten Minahasa Utara. AGRISOSIOEKONOMI. Manado.

Sondakh, J , A. W Rauf, dan J. H. Rembang, 2017. Analisis Produksi Dan Rantai Pemasaran Jagung Di Kabupaten Minahasa Selatan Provinsi Sulawesi Utara. Jurnal Pengkajian Dan Pengembangan Teknologi Pertanian. Manado.

Widayanti, S. 2008. Analisis Efisiensi Pemasaran Talas Di Kecamatan Taman Sari, Kabupaten Bogor, Jawa Barat (Skripsi). IPB. 